\title{
Social Commentaries in T.S. Eliot's Sweeney among the Nightingales
}

\section{OPEN ACCESS}

Manuscript ID:

ENG-2020-09013332

Volume: 9

Issue: 1

Month: December

Year: 2020

P-ISSN: 2320-2645

E-ISSN: 2582-3531

Received: 18.07.2020

Accepted: 25.10.2020

Published: 01.12.2020

Citation:

Gabriel Karthick, K. "Social Commentaries in T.S.

Eliot's Sweeney among the Nightingales." Shanlax International Journal of English, vol. 9, no. 1, 2020, pp. 29-31.

DOI:

https://doi.org/10.34293/

english.v9i1.3332

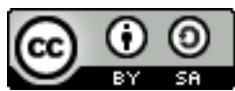

This work is licensed under a Creative Commons Attribution-ShareAlike 4.0 International License

\author{
K. Gabriel Karthick \\ Assistant Professor of English, Voorhees College, Vellore, Tamil Nadu, India \\ https://orcid.org/0000-0003-0271-9740
}

\section{Abstract}

This paper analyses the social commentaries in T.S. Eliot's Sweeney among the Nightingales. As we all know that Eliot was a well known expert in using social themes in his poetic works. It shows his deepest concerns for modern society. He had brought out the primitive instincts and other vices of mankind that ultimately end in its own destruction. The main objective of this paper is to analyse the reasons for the destructive nature of mankind with special focus on social themes expressed by Eliot is his poetic work.

Keywords: T.S. Eliot, Sweeney, Agamemnon, Primitive instincts, Mankind.

As a modernist work, the poem presents its characters as mundane and vulgar rather than as romantic or heroic, like the characters in many poems of the modern century. Its attitude toward modern man is pessimistic rather than optimistic, cynical rather than idealistic. Like many other modernist poetic works, its language is difficult and richly allusive. The poem was wellregarded for its social themes and mainly for its allusion to Agamemnon, a Greek tragedy.

\section{Primitiveness of Mankind}

As we all know that Eliot was a well-known expert in use of themes in his poetic works. Most of his themes are social themes that stand as examples for his concern on modern society. Likewise, he had composed this poem Sweeney among the Nightingales by applying social themes that mostly deal with the people in modern society. He had brought out the primitive instincts that still prevail even in a modern man through his depiction of the main character of the poem Sweeney, a beast like human.

Like many modernist writers, Eliot wanted his poetry to express the fragile psychological state of humanity. The passing of Victorian ideals and the trauma of World War 1 challenged cultural notions of masculine identity, causing artists to question the romantic literary ideal of a visionary poet capable of changing the world through verse. Thus, Eliot realized his real duty to compose poetry with social responsibility. According to him, it is a duty of a writer to expose the evils in society and eradicate them. He believed that a writer has got the innate social responsibility to be reflected in his writings.

Eliot had revealed his wish to transform the modern society from all its irregularities through his works. Eliot strongly believed that the society was paralyzed and wounded, and he saw that culture and dissolving. All his poems demonstrate this sense of indecisive paralysis. An idea that Eliot explored in many works is that humanity's collectively damaged psyche prevented people from communicating with one another. Like other modern writers, Eliot too wanted to capture the transformed world, which they perceived as fractured, alienated and denigrated by the social evils. 
In Sweeney among the Nightingales, Eliot had reflected his opinions on modern society which has been locked by wars, crimes, betrayal, infidelity, mockery and etc. He had mastered the art to expose the primitive instincts of modern man.

Eliot in Sweeney among the Nightingales argues that even a modern man doesn't really mean a modern man. According to Eliot, mankind has witnessed development in outward appearance but nothing has got changed in inner mind. A modern man though seems to be developed, educated, civilized but in reality he possesses all the characters of a primitive man. Thus, man in the modern century has got all primitive instincts into him. War, pride, jealousy, infidelity, adultery, murder, exploitation and, etc are considered as the primitive instincts of mankind. Evil things that come upon the mankind are the consequences of the evil deeds that men do. Nearly all characters in the poem - Sweeney, Lady in the cape, the silent man, Rachel nee Rabinovitch, Agamemnon are immoral characters representing primitive instincts. Initially all these characters seemed to be unrelated but in the process of time their secret union is revealed.

Actually, the lady in cape and the Jewish woman, Rachel nee Rabinovitch were in secret union in order to execute their plot to murder Sweeney. But the mystery behind their conspiracy to kill Sweeney is kept secret unlike that of Agamemnon who was brutally murdered by his wife Clytemnestra in retaliation to his unfaithfulness. The secrecy of conspiracy against Sweeney leads to several speculations with reference to the allusion to Agamemnon. The silent man who was referred as a vertebrate sometimes believed to be the husband of the Jewish woman, Rachel nee Rabinovitch. But this is just a speculation. Next speculation is that though he might not be the husband of Rachel, he was the one who was aware of the silent conspiracy of those two women or otherwise believed to be a part of it.

Sweeney himself was the total representative of the concept Primitiveness of Mankind because his cruel and brutish nature of Sweeney was revealed by his appearance - a combination of an ape, a zebra, and a giraffe. Primitive man was known by his brutish nature and beast like appearance. All these comparisons of Sweeney with animals relates to the beast characters (primitive nature) of mankind. Thus it is very clear that Eliot attacks the modern society that declares itself as a civilized one for its real barbarous nature. The primitive instincts of these characters such as infidelity, vengeance, betrayal, false love, blood thirst and etc are revealed in poem.

\section{Vengeance}

Both Sweeney and Agamemnon had met with the same fate. The fate was the bothe of the were brutally murdered at the hands of women. It is very obvious that their deaths were acts of vengeance for their evil deeds. Sweeney was killed by the two women in secret union, the lady in cape and the Jewish woman, Rachel nee Rabinovitch. Obviously, Sweeney was given several warnings from nature, the silent man and even by the weird behavior of two women conspirators at the restaurant. Though there was no clear disclosure of Sweeney evil deeds in the past, it was so easy to perceive his cruel and brutish nature through the way Eliot described his appearance at the beginning of the poem. It is believed that Sweeney might have abused the two women directly or indirectly in the past. His evil deeds that might be abuse of women, murders or brutish nature would have cost his life at the murderous hands of the plotters.

Agamemnon, the tragic hero of the Greek tragedy was being resembled by the Sweeney. Both of them were killed by the conspiracy of women in union with secret assistance from few men. It is believed that the two women who had killed Sweeney might have been secretly assisted by the silent man in their plot execution. Likewise, Clytemnestra, the wife of Agamemnon who murdered her own husband was provided secret assistance by her secret lover. But the reason for vengeance in the case of Agamemnon was disclosed. He had killed his own daughter, Iphigenia in order to escape from the wrath of Goddess Artemis and had taken many women as his wives during the Trojan War. All this had enraged his wife, Clytemnestra and made her to avenge the death of her daughter by killing her husband.

She had justified his murder by telling the citizens of her country that she killed Agamemnon to avenge the death of Iphigenia and to vent the anger at his unfaithfulness. In other play of Aeschylus, the children of Agamemnon and Clytemnestra avenge the death of their father by killing their 
mother, but the story has no bearing on the subject at hand. Thus, Vengeance forms the central part of the poem. Through this poem, Eliot had taken a strong opposing stand against the avenging minds of mankind who want to kill their opponents in order to retaliate for their evil deeds committed against them in the past. He too suggested that wars are nothing but consequences of vengeance.

\section{Infidelity}

Eliot was well-known as an advocate of moralities in real life. He had attacked the modern world for its immoralities that lead to its own destruction. Infidelity is one of the immoralities that prevail in most of the human beings. In this poem, infidelity was the main cause for the fall of the two protagonists namely Sweeney and Agamemnon. In this poem, both Sweeney and Agamemnon were facing the wrath of death for their infidelity. Obviously, Agamemnon's infidelity directly related to the first kind - unfaithfulness to his spouse. But there is confusion in case of Sweeney because reason for his death at hands of two women was not clear. Obviously, his infidelity was cause for his demise.

It is perceived that unlike Agamemnon, Sweeney's infidelity mostly deals with the second type - disbelief in religion. But this has not been proved or clarified. It is understood that Sweeney never had faith in spirituality and so he was given a last opportunity through the spiritual symbols (nightingales singing near the convent). But because of his extreme pride, he deliberately ignored it. Hence, he was killed by the women in secret league. But in the case of Agamemnon, it was clearly explained that his infidelity was the reason for his brutal death. His wife, Clytemnestra had herself justified his death by telling the citizens that she killed her husband to avenge the death of Iphigenia and to vent her anger at his infidelity. On contrast, we should know that Clytemnestra took infidelity as a weapon to retaliate her husband's infidelity. Therefore, she had taken a lover of her own with whom she plotted the murder of Agamemnon.

\section{War and Pride}

War and Pride are the two innate qualities of mankind. Both are the marginal but vital themes of the poem. Eliot had included both themes as the inevitable part of the poem. It is noteworthy that this poem was composed during the period of World War. There are some personal reasons for Eliot to include these themes in his work. We know that Eliot was unable to receive graduation due to war. This had personally affected him lot. So, it could be interpreted that Eliot might have expressed his frustration through this poem. He had strongly attacked the entire mankind as the sole reason for wars. Greedy nature of mankind would finally result in wars. This has been evident in history through many instances. One can easily perceive an idea of parallelism drawn between Agamemnon and Adolf Hitler whose ambitious nature resulted in the Trojan War and Second World War respectively. But the protagonist Sweeney was never related to any war directly. Thus, it is evident that Eliot had expressed his suggestions and counsel regarding wars and his intention to correct the mankind in order to prevent this World from entering into another war.

\section{References}

Eliot, T.S. "Sweeney among the Nightingales." Poetry Foundation, https://www. poetryfoundation.org/poems/52564/sweeneyamong-the-nightingales

Sinha, Arun Kumar, and Vikram, Kumar. T.S. Eliot: An Intensive Study of Selected Poems, Spectrum Books Private Limited, 2018.

"Sweeney among the Nightingales Analysis." Poem Analysis, https://poemanalysis.com/t-s-eliot/ sweeney-among-the-nightingales

"Sweeney among the Nightingales by T.S. Eliot: Summary and Analysis." Bachelor and Master, https://www.bachelorandmaster. com/britishandamericanpoetry/sweeneyamong-the-nightingales.html\#.Xxl-p6BN2yU.

"T.S. Eliot." Wikipedia, https://en.m.wikipedia.org/ wiki/T._S._Eliot

\section{Author Details}

K. Gabriel Karthick, Assistant Professor of English, Voorhees College, Vellore, Tamil Nadu, India, Email ID: karthick.krish@rocketmail.com. 